\title{
Prediction of Bovine Blood Plasma Cholesterol by Near Infrared Spectrophotometry
}

\author{
Takashi HAYASHI, Miharu YONAI*, \\ Kazuhiro SHIMADA and Fuminori TERADA \\ National Institute of Animal Industry, Tsukuba Norin Kenkyu Danchi, \\ Ibaraki-ken 305-0901 \\ * Tohoku National Agricultural Experiment Station, Morioka-shi 020-0123
}

(Received January 7, 1998)

\begin{abstract}
A near infrared spectrophotometry method is one of the nondestructive measurement techniques of live body information, and development and application of new technique are advanced. If the relevance of the composition and the near infrared spectra of blood plasma of animals is found out, rapid measurement of blood plasma composition will be attained. One hundred and ninety blood samples were collected from beef cattle and dairy cows, and the blood plasma were analyzed. The analyzed blood plasma compositions were as follows ; total protein (TP), albumin (Alb), urea nitrogen (UN), glucose (Glu), tri-glyceride (TG), phospho-lipid (PL), free cholesterol (Fcho), total cholesterol (Tcho), inorganic phosphorus (P), calcium ( $\mathrm{Ca}$ ), sodium ( $\mathrm{Na}$ ), potassium $(\mathrm{K})$, and chlorine $(\mathrm{Cl})$. After thawing the samples, visible and the near infrared spectra $(400-2500 \mathrm{~nm})$ of transmittable light were measured by the near infrared spectrophotometer (NIRSystems 6500) at intervals of the wavelength of $2 \mathrm{~nm}$. The first and second derivatives of the spectra were calculated. After, raw spectra and derivatives were made into independent variables, and all blood plasma compositions were set to objective variables, stepwise multiple regression analysis by SAS was performed. Consequently, 0.95 or more coefficients of determination of an estimation formula were obtained for Tcho, Fcho, and PL after 5 steps of the multiple regression analysis. Furthermore, 0.97 or more coefficients of determination were obtained from the result of a validation by taking in seven or more variables of first and second derivative to the prediction equation for Tcho and $\mathrm{Fcho}$. When five or more independent variables were taken in by the prediction equation of PL after a validation, 0.97 or more coefficients of determination were obtained. On the one hand, when the prediction equations for UN, Alb, and Glu took in four or more independent variables, the coefficient of determination after validation exceeded 0.5 slightly. From the above results, it was shown that prediction of Tcho, Fcho and PL in the blood plasma by the near infrared spectra is possible.
\end{abstract}

Anim. Sci. Technol. (Jpn.) 69 (7) : 674-682, 1998

Key words : Near infrared, Spectra, Bovine blood plasma, Cholesterol

Near infrared spectrophotometry method is considered as one of the nondestructive measurement techniques on roughage and food analysis, and development and application of new technique are advanced. Norris et al. ${ }^{6}$ ) performed composition analysis and digestion tests on hay and silage of alfalfa and fescue, and measured the near infrared reflectance spectra of the powdered samples. Crude protein and NDF content were predicted with high precision by using 9 waves of near infrared band. Mizuno et al. ${ }^{3)}$ also estimated the compositions and the nutrition values of grass by the near infrared spectrophotometry. In the field of food analysis, Sato ${ }^{8)}$ measured the near infrared spectra of edible oil, such as sunflower 
oil, and classified oil by difference of fatty acid composition using principal component analysis. Near infrared spectrophotometry was applied also to control fermentation process ${ }^{1)}$, and to the development of the monitoring technique of glucose and glutamine. On the one hand, the near infrared spectrophotometry method as the monitoring technique of live body information was applied to measurement ${ }^{2)}$ of the metabolism activity of human brain. The technique is expected to diagnose the brain of newborn infant. It is considered that near infrared spectrophotometry method has a possibility of being applied to measurement of live body composition and collection of live body information in the near future. In the field of animal production, the biochemical compositions of the blood plasma of dairy cow and beef cattle are considered as important information which shows physiological and nutritional state of live body. The information is essential to control nutrition and health in feeding and management for cattle. If blood plasma compositions can be analyzed by the near infrared spectrophotometry, the measurement cost of the compositions will be more inexpensive than an auto-analyzer. However, few studies have been reported on the relation of the compositions and the near infrared spectra of the blood of animal containing livestock. If the relevance of the near infrared spectra and the compositions of the blood plasma of mammalian is found out, we can predict the blood plasma compositions from the spectra information. It is possible to perform measurement of a near infrared spectra for a short time, and the measurement procedure of a liquid sample is simple. Since reagent is unnecessary in the measurement of near infrared spectra, there in no danger of discharging hazardous wastes. Thus, development of the new technique of blood plasma analysis is expected.

\section{Materials and Methods}

Blood samples were collected from beef cattle and dairy cows which were held in National Institute of Animal Industry and Tohoku National Agricultural Experiment Station, and 190 blood plasma samples were frozen and preserved. These samples were thawed and analyzed by the auto-analyzer (Hitachi 7070). The analyzed blood plasma compositions are as follows, total protein (TP), albumin (Aib), urea nitrogen (UN), glucose (Glu), triglyceride (TG), phospho-lipid (PL), free cholesterol (Fcho), total cholesterol (Tcho), inorganic phosphorus $(\mathrm{P})$, calcium $(\mathrm{Ca})$, sodium $(\mathrm{Na})$, potassium $(\mathrm{K})$, and chlorine $(\mathrm{Cl})$. The blood plasma samples were frozen again and preserved. The near infrared transmittance spectra of these samples were measured by the near infrared spectrophotometer (NIRSystems 6500) after thawing. The light path of the near infrared spectrophotometer was $1 \mathrm{~mm}$, and quart $z$ cells were used. Visible and near infrared spectra $(400-2500 \mathrm{~nm})$ of transmittable light were measured at intervals of the wavelength of $2 \mathrm{~nm}$. The raw data of the spectra were transmitted to UNIX server system (HP 9000) via developed converter from the near infrared spectrophotometry system. A difference for derivatives was set at $8 \mathrm{~nm}$, and the first and the second derivatives of the spectra were calculated. Since the variances of the second derivative values were excessive, variable conversion was performed in order to equalize the variances. The square root of the original absolute value of a second derivative was calculated, and the original sign was attached.

The first and the converted second deriva. tive, data for every wavelength of $4 \mathrm{~nm}$ was chosen, and a total of 1569 independent varia. bles were eventually obtained. All blood plasma compositions were set to the objective variables, and stepwise multiple regression analysis by $\mathrm{SAS}^{7)}$ was performed. The server system (HP9000) of Computing Center for 
Research in Agriculture, Forestry and Fishery was used for these calculation.

\section{Results and Discussion}

The averages and the standard deviations of the biochemical analysis value of 190 blood plasma samples were $6.4 \pm 0.7,2.9 \pm 0.3 \mathrm{~g} / \mathrm{d} l$ and $8.0 \pm 4.3 \mathrm{mg} / \mathrm{d} l$ of TP, Alb, and UN, respectively. Although the average values of TP and Alb were within the limits of normal values ${ }^{4)}$, UN was a little low. The averages of Glu and TG were $76.5 \pm 9.4$ and $10.7 \pm 3.6 \mathrm{mg} / \mathrm{d} l$, respectively, and Glu was slightly higher than the maximum of normal value ${ }^{4)}$. The averages of PL, Fcho, and Tcho were $125.5 \pm 52.7,17.4 \pm 8.9$ and $97.4 \pm 44.2 \mathrm{mg} / \mathrm{d} l$, respectively. The average of Fcho was slightly lower than the minimum of normal value ${ }^{4)}$.

Inorganic phosphorus and calcium were 6.6 \pm 0.9 and $9.1 \pm 0.7 \mathrm{mg} / \mathrm{d} l$, respectively, and calcium was slightly lower than the minimum of normal value ${ }^{4}$.

Sodium, $\mathrm{K}$, and $\mathrm{Cl}$ were $142.8 \pm 5.9,4.2 \pm 0.3$, and $103.7 \pm 4.1 \mathrm{mEq} / l$. The average of $\mathrm{Na}, \mathrm{K}$, and $\mathrm{Cl}$ was within the limits of normal value ${ }^{4)}$.
Although the near infrared spectra of the blood plasma sample was measured, there was a close resemblance between the raw spectra of the blood plasma and the spectra of distilled water. In the spectra of blood plasma, excessive absorption peaks considered to originate from water near 970,450 , and $1930 \mathrm{~nm}$ were observed (Fig. 1).

In visible band, absorption considered to originate from the substance with yellow color, such as carotene, was detected. Averages and the standard deviations of these spectra were calculated. The variances of the raw data were smaller compared with the averages. In the first derivative, some variances were detected in the full band of wavelength. Moreover in the second derivative, comparatively large variances were detected in the wide range from short to long wavelength.

The data set of the spectra and the blood plasma compositions were divided into 60 and $40 \%$ at random, and the former was used for calibration and the latter was used for validation. Each blood plasma composition was made into objective variables, and stepwise

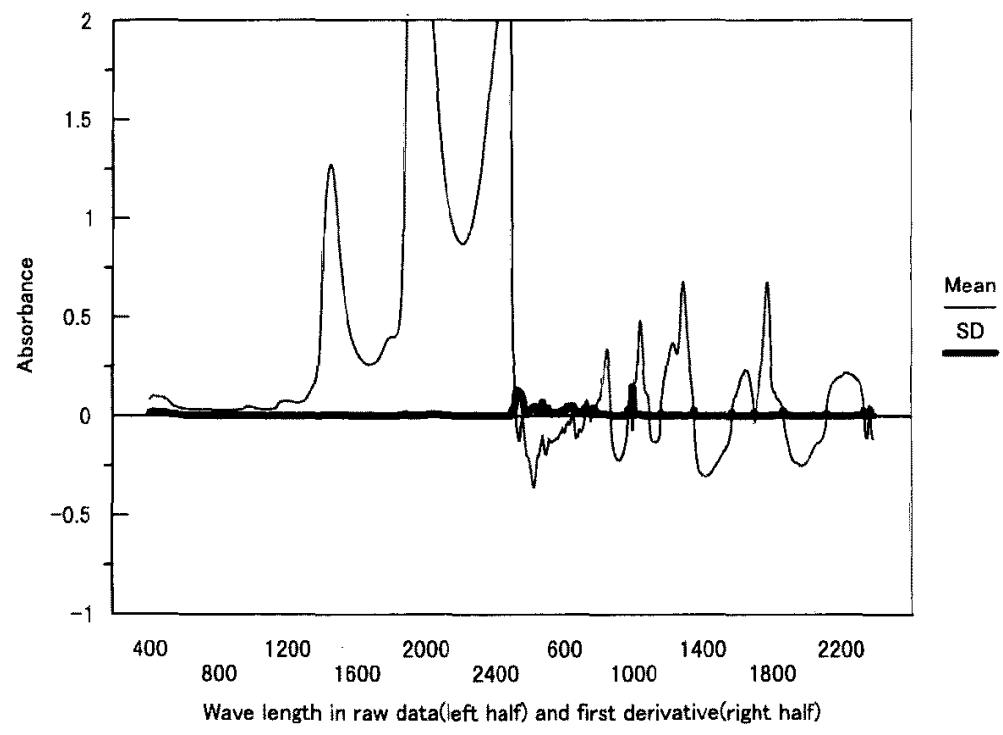

Fig. 1. Mean and SD (standard deviation) of near infrared spectra and it's first derivative of bovine blood plasma. 
multiple regression analyses where the raw data, the first derivative, and the converted second derivative considered as independent variables were performed for the calibration.

Although it is rare that the raw data of spectra are taken into the multiple regression equations regarding all blood plasma compositions, it was shown that the variables of the first and the second derivative were taken into the equations in many cases as independent variables.

Decimal nine or more coefficients of determination were obtained by taking in 30 independent variables to multiple regression equations about all blood plasma compositions (Fig. 2). In the process of each multiple regression analysis of Tcho, Fcho, and PL, 0.95 or more coefficients of determination were obtained after 5 step. However there was a possibility of the over-fitting by the noise of the spectra about many blood plasma compositions other than cholesterol.

By the results of validation, 0.97 or more coefficients of determination were obtained by taking in seven or more variables of the first and second derivatives to prediction equations by Tcho and Fcho (Fig. 3). Moreover in the validation of $\mathrm{PL}, 0.97$ or more coefficients of determination were obtained by taking in five or more independent variables to the prediction equation.

Since it was confirmed that protein content in feed had been predicted in high accuracy), high prediction accuracy was expected of TP in the early stages of this study. However the coefficient of determination of the prediction value to the measurement value for $\mathrm{TP}$ did not exceed 0.7. When four or more independent variables of UN, Alb, and Glu were taken into

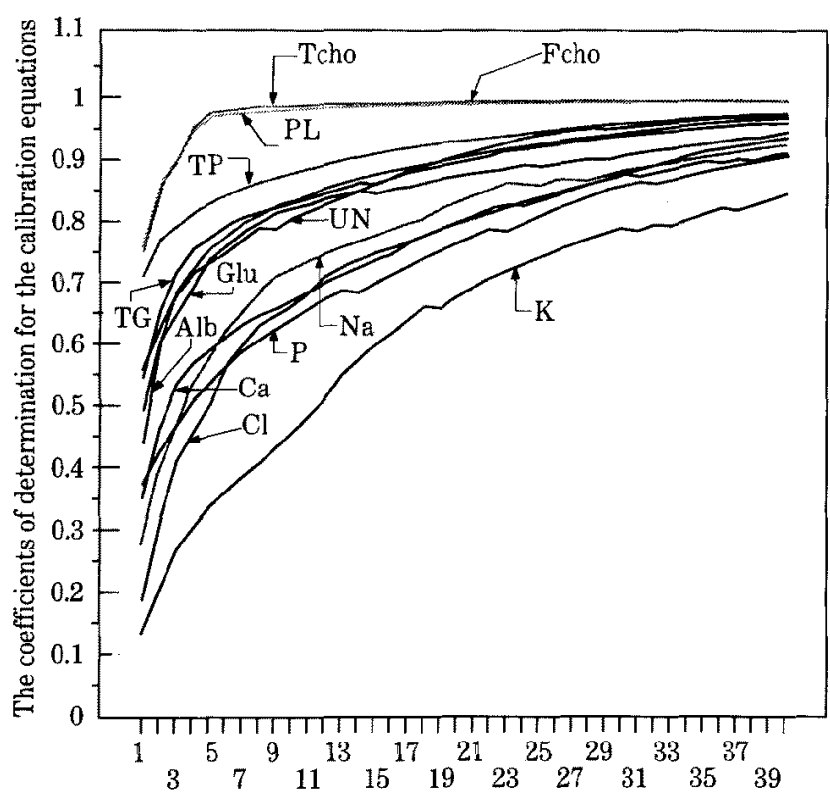

The steps on the stepwise procedure of multiple regression analysis

Fig. 2. Multiple regression analysis for estimation on blood plasma constituents from non infrared spectra and its derivatives.

Alb, albumin ; K, potassium ; Tcho, total cholesterol ; Ca, calcium ; Na, sodium ; TG, tri-glyceride ; $\mathrm{Cl}$, chlorine ; $\mathrm{P}$, inorganic phosphorus ; TP, total protein ; Fcho, free cholesterol ; PL, phospholipid ; UN, urea nitrogen ; Glu, glucose. 


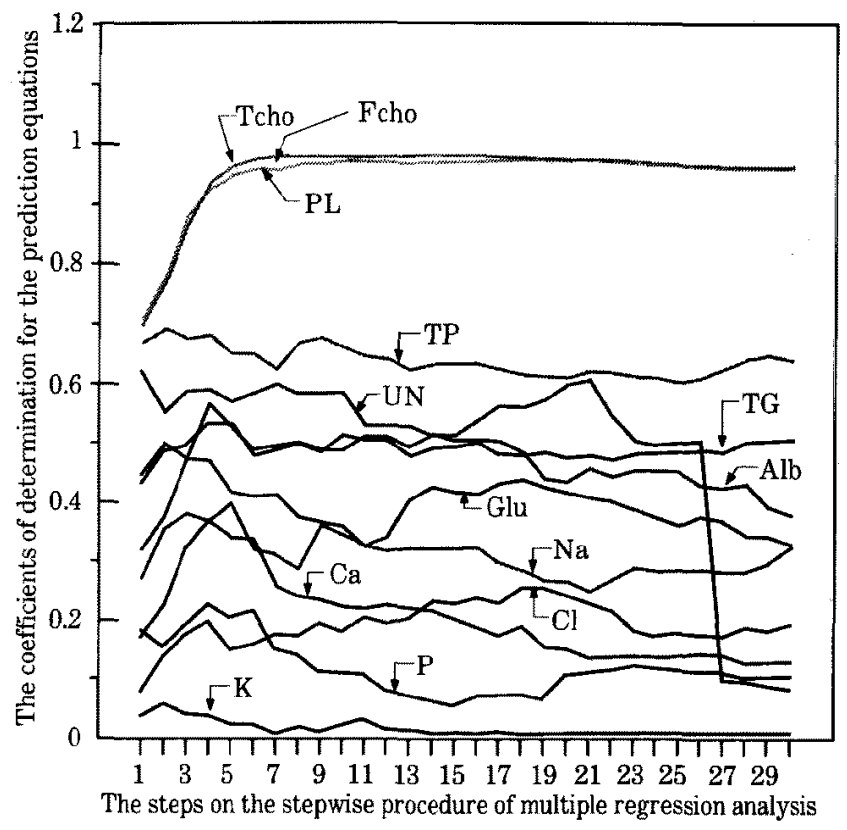

Fig. 3. Validation for the prediction equations on the blood plasma constituents from non infrared spectra and its derivatives.

Alb, albumin ; K, potassium ; Tcho, total cholesterol ; Ca, calcium ; Na, sodium ; TG, tri-glyceride ; $\mathrm{Cl}$, chlorine ; $\mathrm{P}$, inorganic phosphorus ; TP, total protein ; Fcho, free cholesterol ; PL, phospholipid ; UN, urea nitrogen ; Glu, glucose.

the prediction equation, 0.5 or more coefficients of determination were obtained. This coefficients of determination were considered to be practically inadequate. In addition, the coefficient of determination of the prediction equation of TG was 0.5 , that of $\mathrm{Na}$ and $\mathrm{Ca}$ was 0.4 or less. Since each correlation of the predicted values and the measurement value of $\mathrm{P}, \mathrm{Cl}$, and $\mathrm{K}$ was low, it was thought that the prediction for the inorganic matters by the near infrared spectrophotometry was difficult.

As shown in Table 1, the most effective wavelengths in the prediction of Fcho were 1728 and $1696 \mathrm{~nm}$ in the first derivative. From the result, the slope near these wavelengths in raw spectra was considered to be important. The result of multiple regression analysis of PL is shown in Table 2.

The $F$ value of the absorbance in $1480 \mathrm{~nm}$ of the raw spectra and the first derivative in 1688 nm was large especially in the independent variables. Since the prediction equation for PL had only a small number of independent variable, it was considered to be practically sufficient.

The result of multiple regression analysis of Tcho is shown in Table 3. The first derivatives of 1728 and $1696 \mathrm{~nm}$ were important as independent variables in the prediction of Tcho which was the same as that of Fcho. Furthermore, it was also as common as Fcho that the first derivative of $1688 \mathrm{~nm}$ and the second derivative of $1692 \mathrm{~nm}$ were taken into the independent variables of the prediction equation. Since Fcho and Tcho had many common chemical features, the result above showed that both were closely related also in near infrared spectrophotometry.

Distribution of the predicted and the actual measurement values of Fcho, PL, and Tcho is 


\section{Prediction of Blood Cholesterol by NIR}

Table 1. Variables entered and their regression coefficients in model for analysis on the relation between free cholesterol concentration in blood plasma and near infrared (NIR) spectra

\begin{tabular}{crrrrr}
\hline Variable & $\begin{array}{c}\text { Parameter } \\
\text { estimate }\end{array}$ & $\begin{array}{c}\text { Standard } \\
\text { error }\end{array}$ & $\begin{array}{c}\text { Sum of } \\
\text { squares }\end{array}$ & F & Prob>F \\
\hline INTERCEP & -67.84 & 83.46 & 1.43 & 0.66 & 0.4178 \\
984der1 & 451.81 & 80.93 & 67.63 & 31.16 & 0.0001 \\
1196der1 & 250.10 & 55.65 & 43.82 & 20.19 & 0.0001 \\
1688der1 & 844.67 & 268.83 & 21.42 & 9.87 & 0.0021 \\
1696der1 & 2821.18 & 233.17 & 317.67 & 146.38 & 0.0001 \\
1728der1 & -2530.64 & 208.27 & 320.39 & 147.64 & 0.0001 \\
2132der1 & -1673.33 & 353.65 & 48.58 & 22.39 & 0.0001 \\
1692der2 & -40.38 & 28.67 & 4.30 & 1.98 & 0.1614 \\
\hline
\end{tabular}

The count of data and the coefficient of datermination are 137 and 0.977. INTERCEP, 984der1 and 1692der2 in variable column showed intercept for objective variable, first derivative for absorbance on $984 \mathrm{~nm}$ and second derivative for ones on $1692 \mathrm{~nm}$ by NIR spectrophotometry. The analysis and tests are carried out by SAS system.

Table 2. Variables entered and their regression coefficients in model for analysis on the relation between phospho-lipid concentration in blood plasma and near infrared (NIR) spectra

\begin{tabular}{lrrrrr}
\hline Variable & $\begin{array}{c}\text { Parameter } \\
\text { estimate }\end{array}$ & $\begin{array}{c}\text { Standard } \\
\text { error }\end{array}$ & $\begin{array}{c}\text { Sum of } \\
\text { squares }\end{array}$ & $\mathrm{F}$ & Prob $>\mathrm{F}$ \\
\hline INTERCEP & -8528.55 & 670.70 & 13883.69 & 161.69 & 0.0001 \\
1480raw & 7738.61 & 329.60 & 47333.10 & 551.24 & 0.0001 \\
1808raw & -5104.65 & 931.76 & 2577.17 & 30.01 & 0.0001 \\
1688der1 & 21115.50 & 934.49 & 43840.42 & 510.57 & 0.0001 \\
2132der1 & -5685.65 & 2023.25 & 678.08 & 7.90 & 0.0057 \\
1708der2 & -2689.13 & 263.11 & 8969.15 & 104.46 & 0.0001 \\
\hline
\end{tabular}

The count of data and the coefficient of determination are 137 and $0.973 . \quad 1480$ raw in variable column showed raw data of absorbance on $1480 \mathrm{~nm}$ by NIR spectrophotometry. Other abbreviations are the same as that of Table 1.

Table 3. Variables entered and their regression coefficients in model for analysis on the relation between total cholesterol concentration in blood plasma and near infrared (NIR) spectra

\begin{tabular}{lrrrrr}
\hline \hline Variable & $\begin{array}{c}\text { Parameter } \\
\text { estimate }\end{array}$ & $\begin{array}{c}\text { Standard } \\
\text { error }\end{array}$ & $\begin{array}{c}\text { Sum of } \\
\text { squares }\end{array}$ & $\mathrm{F}$ & Prob $>\mathrm{F}$ \\
\hline INTERCEP & -2181.52 & 495.05 & 748.01 & 19.42 & 0.0001 \\
1576der1 & -14969.55 & 2405.89 & 1491.30 & 38.71 & 0.0001 \\
1688der1 & 6507.74 & 1217.78 & 1100.07 & 28.56 & 0.0001 \\
1696der1 & 10939.98 & 913.44 & 5525.47 & 143.44 & 0.0001 \\
1728der1 & -20303.53 & 818.32 & 23713.40 & 615.59 & 0.0001 \\
2132der1 & -5439.82 & 1670.15 & 408.65 & 10.61 & 0.0014 \\
1660der2 & 150.41 & 29.31 & 1014.35 & 26.33 & 0.0001 \\
1692der2 & -183.22 & 118.94 & 91.41 & 2.37 & 0.1259 \\
\hline
\end{tabular}

The count of data and the coefficient of determination are 137 and 0.983 .

Other abbreviations are the same as that of Table 1. 


\section{HAYASHI, YONAI, SHIMADA and TERADA}

plotted in Fig. 4. Although a part of data were focused on the lower zone, all the data were mostly located on the diagonal line. The aver- ages of Fcho, PL and Tcho were 17.4 $\pm 8.9,125.5$ \pm 52.7 and $97.4 \pm 44.2 \mathrm{mg} / \mathrm{d} l$, respectively. The prediction errors of Fcho, PL and Tcho were

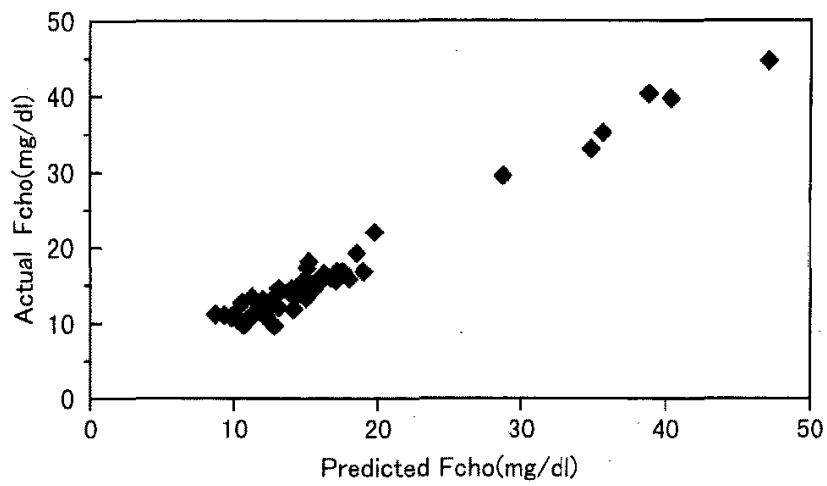

$y=-0.221+1.016 x, r^{\wedge} 2=0.971$, Pred.Err. $: 1.37$

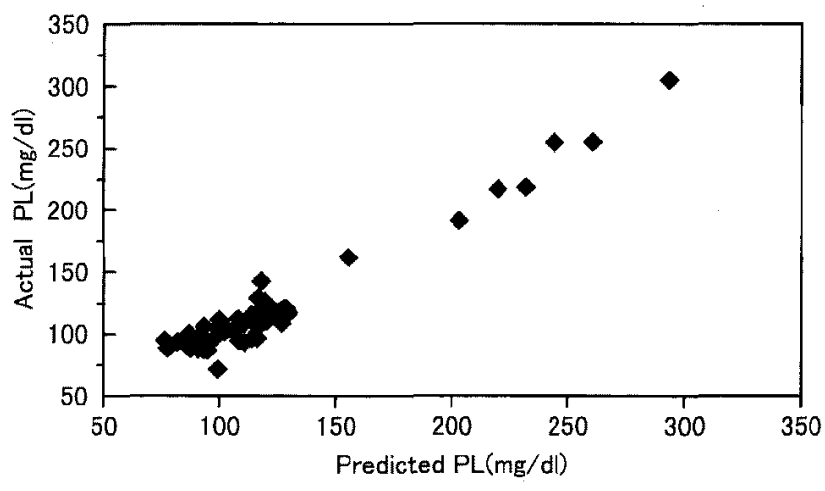

$y=2.159+0.970 x, r^{\wedge} 2=0.970$, Pred.Err.: 9.62

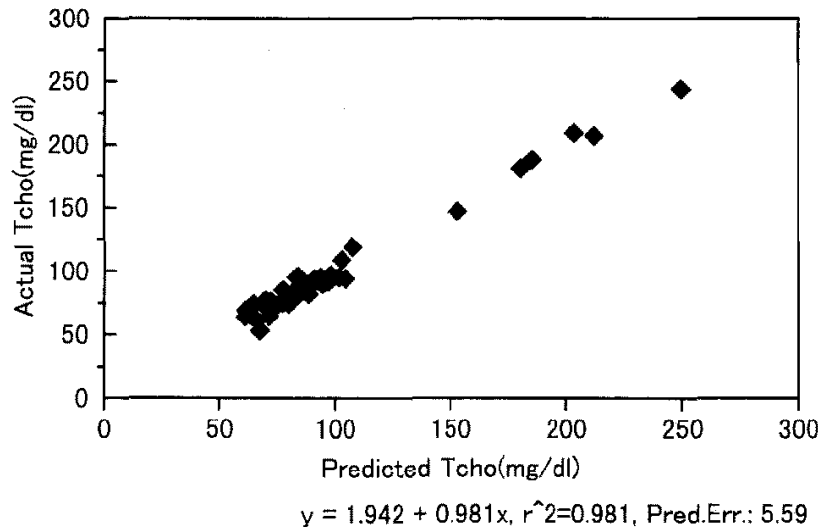

Fig. 4. Scattering plot and regression equations between predicted and actual values on Fcho (free cholesterol), PL (phospho-lipid) and Tcho (total cholesterol). 
1.37, 9.62 and $5.59(\mathrm{mg} / \mathrm{dl})$, respectively. Near infrared spectrophotometry method of Fcho, $\mathrm{PL}$ and Tcho in bovine blood plasma was considered to have an accuracy equivalent to the practical chemical analysis.

Potassium, $\mathrm{Cl}$, and $\mathrm{P}$ had low concentration in blood plasma, and their absorption of near infrared band were very weak. From these, it is suggested that a better technique is required for the prediction of inorganic matters by the near infrared spectra. If the information on cholesterol concentration in blood plasma of cattle is obtained rapidly, the information is applicable to the improvement of feeding and management.

Positive correlation was confirmed by Tcho concentration in bovine blood serum on the first half of fattening period and the hypodermic fat thickness of the carcass, when Nishimura et $a{ }^{5}{ }^{5}$ investigated the alteration of serum lipid in fattening process of Japanese Black steers. Yonai et al.$^{9)}$ measured total cholesterol, tri-glyceride and non-esterified fatty acid in blood plasma of Japanese Black cows. They confirmed the relevance of the days needed for estrus return and the rise of the concentration of total cholesterol during postpartum period. It is considered that the alteration of cholesterol in bovine blood plasma is closely associated with economic traits as mentioned above. Although the information on blood plasma cholesterol is necessary to control the nutrition and health of dairy cow and beef cattle, analysis of blood by the conventional method has taken considerable time and expense.

It was shown that the prediction equation from the raw data, the first and the second derivative of near infrared spectra obtained in this study could estimate Tcho, Fcho and PL in bovine blood plasma in high accuracy. The prediction accuracy of $\mathrm{TP}, \mathrm{Alb}$, and $\mathrm{UN}$ needs an improved analytical technique.

This study was the project of Bio-oriented Technology Research Advancement Institution.

\section{Reference}

1) Chung H, Arnold MA, Rhiel M, Murhammer DW. Simultaneous measurement of glucose and glutamine in aqueous solutions by near infrared spectroscopy. Appl. Biochem. Biotechnol., $50:$ 109-125. 1995.

2) Kida I, Yamamoto T, Tamura M. Interpretation of BOLD MRI signals in rat brain using simultaneously measured near infrared spectrophotometric information. NMR in Biomedicine, 9 : 33-338. 1996.

3) Mizuno $K$, Ishiguri $T$, Kondo $T$, Kato $T$. Prediction of forage compositions and sheep responses by near infrared reflectance spectroscopy; evaluation of accuracy. Bull. Natl. Grassland Res. Inst. (Jpn.), 38 : 35 47. 1988.

4) Nakamura $R$ (eds). Veterinary handbook (Jpn.). 1503-1505. Yokendo. Tokyo. 1988.

5) Nishimura $T$, Satou $Y$, Kawasaki $T$, Mori $S$. Interrelationship between carcass characteristics and serum lipids during the fattening period in Japanese Black steers. Bull. Hokkaido Pref. Shintoku Anim. Husb. Exp. Sta. (Jpn.), $16:$ 19-24. 1988.

6) Norris KH, Barnes RF, Moore JE, Shenk JS. Predicting forage quality by infrared reflectance spectroscopy. J. Anim. Sci., 43 : 889-897. 1976.

7) SAS Institute Japan. SAS/STAT user's guide release 6.03 edition. 811-819. SAS Institute Japan. Tokyo. 1993.

8) Sato T. Application of principal component analysis of near infrared spectroscopic data of vegetable oils for their classification. J. American Oil Chemists' Society, $71: 293-298.1994$.

9) Yonai M, Geshi M, Sakaguchi M, Suzuki O. The relationship between the first postpartum estrus and the change of plasma cholesterol concentration during pre- and postpartum in Japanese Black cattle. J. Reprod. Develop. (Jpn.), 41 : j 1-j8. 1995. 


\title{
近赤外スペクトルによるウシ血漿コレステロールの予測
}

\author{
林孝・米内美晴* ·島田和宏 ·寺田文典
}

農林水産省畜産試験場, 茨城県筑波農林研究団地 305-0901

*農林水産省東北農業試験場, 盛岡市 020-0123

\begin{abstract}
近赤外分光法は，生体の非破壊的計測手法の一つであり，新たな分析手法の開発挨よび応用が進める れている，動物の血漿の成分上近赤外スペクトルの関連性が見いだされれば，血嶈成分の迅速な測定が

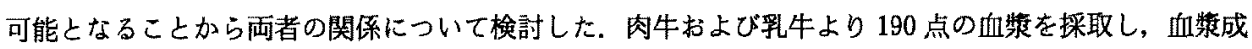
分について分析した．血漿成分の分析項目は，総タンパク (TP)，アルブミン (Alb), 尿菜態窒素 (UN), グルコース (Glu), 中性脂肪 ( $\mathrm{TG})$, リン脂質 ( $\mathrm{PL})$, 遊離コレステロール (Fcho), 総コレステロール (Tcho), 無機リン (P), カルシウム $(\mathrm{Ca})$, ナトリウム $(\mathrm{Na})$, カリウム $(\mathrm{K})$, 塩素 $(\mathrm{Cl})$ とした. 次 に近赤外分光光度計により, 透過光の可視および近赤外スペクトル $(400-2500 \mathrm{~nm})$ を波長 $2 \mathrm{~nm}$ 間隔で 湘定し，スペクトルの一次微分および二次微分を計算した。さらに，原スペクトルと誘導変数を独立変 数とし，血漿成分のすべてを目的变数とする変数增減型時重回㷌分析を行った. その結果, Tcho, Fcho および PLについては，重回州分析の 5 ステップ以降に，推定式の寄与率 0.95 以上が得られた。検証の 結果から，Tchoおよび Fchoに関して一次微分および二次徽分の 7 個以上の変数を予測式に取り込む ことに上り 0.97 以上の寄与率が得られた．PLでは，検証の後に 5 個以上の独立変数を予測式に取り込 むことにより 0.97 以上の寄与率が得られた，一方，UN，Alb および Glu は 4 個以上の独立変数を取り 込むことにより，検証後の奇与率は 0.5 をわずかに超えたに過ぎなかった. 以上の結果から, 近赤外スぺ クトルによる血㯟の中の Tcho, Fcho およよ゙ PL の予測が可能であることが示された.
\end{abstract}

日畜会報, $69(7): 674-682,1998$ 